\title{
BANK CREDIT ACCESSIBILITY FOR SMALL AND MEDIUM ENTERPRISES IN HO CHI MINH CITY, VIETNAM
}

\author{
Ai Huu Tran \\ Thu Nguyen Thi Mong \\ Van Hien University, Ho Chi Minh, Vietnam
}

This study examines the impact of firm characteristics on SMEs' access to bank crediting. The study used primary data taken from a survey questionnaire of 269 SMEs that collected credit-related data concerning SMEs. Regression analysis is applied to identify the factors affecting the accessibility of bank credits. SPSS 22.0 software was used for further analysis. The results show that the characteristics of business affecting the ability to access bank credit include: enterprise's location, equity, business plan, collateral, project value and firm tax number. The factors of business plan and project value are the two most influential ones.

Keywords: credit accessibility, SMEs; business plan; project value; Vietnam

\section{Introduction}

The SME sector's contribution to economic development, job creation, and income enhancement has been recognized worldwide. However, the main problem that restricts the SME sector from fully contributing to the mainstream economy is the lack of finance.

This study is conducted to assess the current situation and difficulties in implementing the Directive No. 03 / CT-NHNN on promoting green credit growth and managing environmental and social risks in credit activities. The following specific questions have been in the focus of our research: How are current environmental and social risks considered and

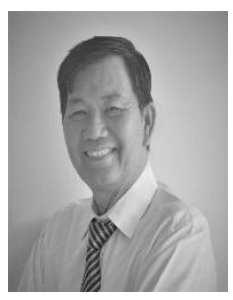

\section{Ai Tran Huu}

$\mathrm{PhD}$, Lecturer at the Faculty of Economics, Van Hien University, Ho Chi Minh City, Vietnam.

Research interests: agricultural products markets; SMEs functioning and government support; organic food markets; environmental issues of economic development; corporate social responsibility.

E-mail: aith@vhu.edu.vn.

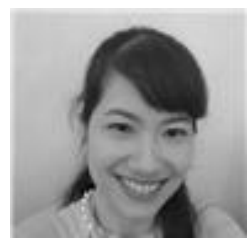

\section{Nguyễn Thị Mộng Thu}

MBA, Lecturer at the Faculty of Economics, Van Hien University, Ho Chi Minh City, Vietnam.

Research interests: SMEs functioning and government support; consumer behavior; innovative products, markets and finances.

E-mail: thuntm@vhu.edu.vn 


\section{BANK CREDIT ACCESSIBILITY FOR SMALL}

assessed in the credit review process of commercial banks? Are there difficulties and barriers in promotion of green credit growth and managing environmental and social risks in credit activities in Vietnam?

The ability to access bank credit is one of the important factors considered in the development of any business. Many SMEs use bank loans as the main source of external capital. Credit availability varies depending on a variety of factors related to business and bank operations. One of the features that can be described as distinguishing credit terms is the size of a business. Although SMEs are important to economic development, they find it difficult to acquire capital due to insufficient information transferred to banks and its asymmetry. However, the better the economic condition of a business and the more information about it available, the easier it will be to access bank capital.

From the academic perspective, the issue of access to finance for businesses is a problem that has received a lot of attention in the recent research. So far, there are two main lines in the research on this topic. One is the study of firms' ability to access capital.

Abor, J. (2007) used a linear probability model applied on SME data from eight Southeast Asian countries to show that enterprises' access to capital depends on business characteristics such as size, the number of years in operation, business lines, the level of development. country, business life cycle, and the type of business. Besides, individual characteristics of business owners such as management experience, financial ability, and managing more than one company also determine the ability of enterprises to access capital. Furthermore, corporate performance in the past, namely, such parameters as profitability and revenue growth, also determine firm's ability to access formal credit.

The second branch studies the results of capital access, the relationship between capital accessibility and the development of firms. Kitindi et al. (2007) used Financial Analysis Made Easy data on 1.8 mln enterprises (both private and public) in the UK and Ireland in the period of 1991-2001, and applied the generalized method of moment (GMM). Their results showed that capital structure has an influence on the growth of business.

\section{Theoretical basis}

\section{Theoretical framework}

Most SMEs rely on internal finance because they cannot afford external finance easily. However, for many of them internal finance is still insufficient for growth and profitability. Most SMEs do not have access to debt, and this is leading to inadequate capital structure. According to (Demirguc-Kunt et al., 2012), the main external sources of finance for SMEs are equity and debt. Shane S. (2008) observed that external equity from stock exchanges (capital markets) almost never exists for SMEs.

Sorooshian et al. (2010) demonstrated that firm characteristics influence capital structure and performance of SMEs. Financial gaps exist between funding availability and the demand for it since in the case of SMEs capital requirements tend to be much stricter.

Capital structure can be described as the combination of debt and equity that a firm uses to finance its operations (Gilbert, 2008). The initial hypothesis of capital structure originates from the Modigliani-Miller theorem which argues that enterprise value is not appropriate in financing decisions in a perfect market (Modigliani et al., 1963). The theory lacks real-world applicability because corporate values are often involved in financial decisions because of agency costs, bankruptcy costs, presence of asymmetric information, 
and tax components affect the structure of enterprises' capital structure. The benefits of using debt in a firm's capital structure exist because interest on the debt is tax-deductible, thus creating tax savings for borrowers (Fatoki \& Asah, 2011). Therefore, it is possible to reduce the cost of capital for enterprises and maximize the wealth of shareholders by renting debt. Tax savings make debt financing cheaper than equity financing whenever it is used in the capital of a structured firm. The combination of cheap debt with relatively expensive equity will reduce the cost of a firm in terms of capital, which is a barrier to the decisions to accept or reject investment.

For any business project to be pursued, it must be feasible to generate enough cash flow to cover the initial costs of the investment. Theory stipulates that an enterprise should have $100 \%$ debt in its capital structure so that a firm can benefit from the tax shield (Modigliani et al., 1963). Stiglitz et al. (1981) stated that the presence of institutional issues such as disproportionate information and ethical hazards can affect SMEs' access to credit and capital structure.

\section{SME perspectives on debt financing}

Constraints that exist in accessing external credit for SMEs have exposed the sector to the impact of industry growth funds (Da Silva et al., 2007). Funding from either internal, or external sources is necessary to stimulate business profitability which is the engine driving the expansion and stability of any business (Myers, 1984). Olutunla et al. (2008) stated that enterprises deciding to finance should prioritize internal credit sources over external credit sources, depending on the availability of sources, expenditures and other fees involved. Internal credit sources are not the preferred option chosen by most businesses in profitable projects, primarily because simple credit is often not enough. Thus, external credit becomes the only source to rescue small and medium businesses in HCM City.

The borrowed funds can be invested in profitable projects to create additional assets that can be used as collateral in the future when enterprises need foreign credit debt. Baculáková \& Grešš (2015) suggested that in the sample of small businesses studied by them, credit interest rates decrease over the time period of cooperation with banks. Collateral requirements are also getting lower and lower. They also found that credit discounts can occur with the length of this cooperation, regardless of the amount (range) of information the bank actually collects. Reducing credit interest rates for the units that demonstrate their ability to complete projects (banks do not expand their knowledge on new elements, but rather analyze only those provided by the businesses themselves).

The level of competition in the banking sector can also affect the relationship between the time of business cooperation with banks and the interest rates. Popkova et al. (2017) argued that interest rates may increase in such cases with the duration of an institution's cooperation with a bank. According to this approach, banks offset the previous risk financing for unknown businesses.

Banks' interest in financing businesses has not been previously tested as a need to attract customers and enhance credit portfolios. In a competitive market, banks tend to adjust their rates of return from credit granting. In their early days of existence, banks provided relatively cheap capital, with these costs increasing over time. It is the result of the fact that banks disvalue the credits granted to young, unknown entities, or they value well-established, mature entities in a very limited way. In addition, banks in the non-competitive market 


\section{BANK CREDIT ACCESSIBILITY FOR SMALL}

believe in future benefits from credit granting to a certain enterprise and that is why they decide to offer relatively cheaper capital for those just starting their business operations.

\section{Factors affecting the ability to access bank credit}

\section{Location of an enterprise}

According to Berger et al. (2006), geographical proximity between the lender and the customer is directly related to business credit accessibility. Lenders that are geographically close to customers are likely to use softly the available qualitative information to build creditworthiness among customers for higher credit quality. Gilbert B. A. (2008) found that a firm's location had a significant relationship with market access, supplies and other resources such as capital, labor and land. For example, urban firms are more likely to succeed than rural firms when it comes to the access to credit, markets and other resources. Fatoki et al. (2011) have found that urban SMEs are more successful in accessing debt than rural SMEs. Physical proximity between a lender and a borrower creates an improved form of scrutiny of the environment that enables SMEs to access credit from the lender. Therefore, there is a positive relationship between firms' location and SMEs' access to debt.

\section{Owners' Equity}

The industry in which business operates does not directly affect its capital structure but can indirectly affect the structure and the nature of firm's assets (Hall et al., 2000). The relationship that exists between industrial classifications and the use of debt in capital structure stems from the theory that industrial classifications are an alternative to business risk (Barbosa, 2004). This theory also indicates that firms operating in the same business sector, environment and are having the same economic characteristics tend to have the same impact faced by the sector that can affect their income and growth.

(Hall et al., 2000) were also advocating that while firm-specific characteristics are sensitive to industry's structural characteristics, the variables of financial strategy also have a very important influence on industry-specific impacts.

Abor J. (2008) provided the evidence showing that SMEs operating in agriculture have the strongest capital structure and asset structure while wholesale and retail sectors have the weakest asset structure and debt ratio. Therefore, it is hypothesized that there exists a positive effect between the industry/sectoral affiliations of firms and their access to debt.

\section{Business plan of the business}

This study assesses why lenders (banks and other lending agencies) are interested in business information on businesses. Kitindi et al.(2007) indicated that lenders use this business information to evaluate both current and future performance of businesses. Lenders want to know the interest and the principal status of their loans by evaluating the capital structure of the business. Furthermore, lenders use business information to determine the creditworthiness of a borrower and then decide whether to grant or extend a loan. Lack of sufficient information leads to information asymmetry and thus can jeopardize access to credit financing (Stepanova et al. 2019). Consequently, a positive relationship exists between business information and SMEs' access to debt. 


\section{Business collateral}

The SME sector has difficulties with accessing external credit for their investment projects due to the lack of collateral. From that point of view, SMEs cannot develop because they do not have collateral to commit to external credit. Coco G. (2000) pointed out that collateral requirements are an important aspect for small and medium businesses trying to succeed in accessing external financing from lenders.

The same author also stated that collateral is lender's protection in case of default. Or in other words, collateral is insurance that the lender's contract will be respected. Collateral addresses the issues of information asymmetry in the evaluation of investment projects, project adequacy, and the risks exposed to borrowers, and the costs associated with monitoring the borrower's character. Barbosa et al. (2004) proposed that firms must own more tangible assets that can create higher value for their business to speed up loan security. Because the higher is the value of an asset, the lower would be the interest rate on the debt secured by it. Hence, our hypothesis is that there exists a strong positive relationship between business collateral and SMEs; access to debt.

\section{Project value}

Businesses that are undertaking investments in risky projects only can generate a higher level of income required to cover the debt. As a result, lenders cannot avoid choosing a more risky project and must therefore accept there is always a risk in business. When the demand is exceeded, the lender has different maximums corresponding to the rates with lower odds of choosing a disadvantageous business to allocate credit (Stiglitz et al, 1981). Furthermore, allocation conditions reduce access to financial resources not only for new investments but also for job creation and poverty alleviation. Another aspect of credit allocation is that employees/managers of financial institutions may be personally liable for inefficient loans if these loans are granted to SMEs without any government guarantees. Regulators are partially responsible for protecting the interests of depositors and the credit allocation conditions.

\section{Firm Tax}

According to Modigliani et al. (1958), the corporate tax hypothesis highlights the important issues related to the financial structure decision: the cost of debt is cheaper than equity; the increase in risk and cost of equity as debt increases; and the benefit of the debt is tax-deductible. They argue that in the absence of taxes, the cost of capital that remains constant for the benefit of cheaper debt is precisely offset by an increase in the cost of equity due to the increased risk. With taxes and the ability to deduct interest, they conclude that businesses should use as much debt as possible.

Myers et al. (1984) described the "static trade-off" theoretical compromise in which firms would use a lot of debt to take advantage of the ability to withhold tax but not so much to avoid an increasing likelihood of costly bankruptcy. Therefore, SMEs can buy credit from financial institutions to meet the recurrent expenditures based on future profits.

\section{Research hypotheses}

H1: Location of a firm/enterprise has a positive effect on the enterprise's ability to access credit.

H2: Owners' equity has a positive effect on firm's ability to access credit. 


\section{BANK CREDIT ACCESSIBILITY FOR SMALL}

H3: Firm's business plan has a positive impact on the ability to access credit.

H4: Firm's collateral has a positive effect on the ability to access credit.

H5: Firm's project value has a positive influence on the ability to access credit.

H6: Firm tax has a positive influence on the ability to access credit.

\section{Research Methods}

\section{Qualitative research}

Qualitative preliminary research has been used to explore, adjust the model, supplement the observed variables and measure the research concepts.

The questionnaire was first piloted on 30 SMEs.

The purpose of the pilot study has been to identify the common problems, but also to incorporate the respondents' opinions to improve the quality of the questionnaire for the purposes of this research.

Then, the research has been conducted through interviews and focus group discussions to find out the most common opinions about the factors affecting the access to bank credit.

The questionnaire surveyed 269 SMEs to collect relevant data on their access to credit.

\section{Quantitative research}

The data has been collected through a survey of businesses with access to bank credit in Ho Chi Minh City.

The questionnaire included 34 questions, of which 30 involved the observed variables under 6 independent scales and 4 observed variables on the dependent scale on the satisfaction level of enterprises using online tax payment services.

The survey was conducted during August 2020, either by means of sending paper questionnaires in person or by emailing the electronic version of the same to the respondents. There were 300 live questionnaires distributed, the total of 282 questionnaires were collected back. 19 questionnaires were removed due to insufficient information provided.

Thus, at the end, 269 questionnaires were used for further analysis.

\section{Results and discussions}

\section{Confirmatory factor analysis (CFA)}

The correlation coefficient between the components with the accompanying standard deviation (see Table 1) shows us that these coefficients are less than 1 (with statistical significance). Therefore, the components of Location of the Firm (LF), Owners' Equity (OE), Firm's Business Plan (BP), Firm's Collateral (FC), Firm's Project Value (PV), and Firm Tax (TN) have distinguishing values. 
Table 1 - Results of testing the components of the scale (Source: authors' own analysis of the research data via SPSS 22.0)

\begin{tabular}{|ccc|cccc|}
\hline & & & Estimate & S.E. & C.R. & P \\
\hline $\mathrm{CF}$ & $<-->$ & $\mathrm{BP}$ & 0.158 & 0.028 & 5.653 & $* * *$ \\
$\mathrm{CF}$ & $<-->$ & $\mathrm{PV}$ & 0.065 & 0.028 & 2.301 & 0.021 \\
$\mathrm{CF}$ & $<-->$ & $\mathrm{LF}$ & 0.157 & 0.028 & 5.537 & $* * *$ \\
$\mathrm{CF}$ & $<-->$ & $\mathrm{OE}$ & 0.166 & 0.029 & 5.821 & $* * *$ \\
$\mathrm{CF}$ & $<->$ & $\mathrm{TN}$ & 0.077 & 0.022 & 3.408 & $* * *$ \\
$\mathrm{BP}$ & $<->$ & $\mathrm{PV}$ & 0.078 & 0.032 & 2.425 & 0.015 \\
$\mathrm{BP}$ & $<-->$ & $\mathrm{LF}$ & 0.179 & 0.032 & 5.546 & $* * *$ \\
$\mathrm{BP}$ & $<-->$ & $\mathrm{OE}$ & 0.236 & 0.035 & 6.821 & $* * *$ \\
$\mathrm{BP}$ & $<-->$ & $\mathrm{TN}$ & 0.155 & 0.029 & 5.338 & $* * *$ \\
$\mathrm{PV}$ & $<-->$ & $\mathrm{LF}$ & 0.121 & 0.035 & 3.484 & $* * *$ \\
$\mathrm{LF}$ & $<->$ & $\mathrm{OE}$ & 0.169 & 0.033 & 5.147 & $* * *$ \\
$\mathrm{LF}$ & $<->$ & $\mathrm{TN}$ & 0.100 & 0.027 & 3.688 & $* * *$ \\
$\mathrm{OE}$ & $<-->$ & $\mathrm{TN}$ & 0.088 & 0.026 & 3.365 & $* * *$ \\
\hline
\end{tabular}

Regarding the relevance general, the linear structural analysis shows that this is a valuable model's chi-squared statistics is 256.707 with 133 degrees of freedom and the value of $\mathrm{p}=0.000$. Chi-squared relative degree of freedom according to $\mathrm{Cmin} / \mathrm{df}$ was $1.930(<2)$. Other indicators are: GIF $=0.910(>0.9)$, TLI $=0.951(>0.9), \mathrm{CFI}=0.962(>0.9)$ and RMSEA $=0.059(<0.08)$. Therefore, this model fits the data collected. This also allows us to draw individual judgments about the direction of the observed variables. The standardized weights of the scales are $>0.5$ and with statistical significance $p<0.05$, so the scale has achieved the convergence value.

\section{Structural Equation Model Results}

Table 2 shows the results for the degree of conformity checking for the two structures, the characteristics of SMEs and the accessibility of credit for SMEs, and the result structure model of the two datasets. Various indices, namely the absolute fit measurements and the increased fit measurements, are used to evaluate a model's fit. As a commonly used statistics for the model suitability index, Chi-square (X2) is used in this study to test the existence of any relationship between the variables in the model. From the AMOS it is clear that the model was consistent with the data and therefore the proposed model is suitable for explaining the relationships between the variables. 


\section{BANK CREDIT ACCESSIBILITY FOR SMALL}

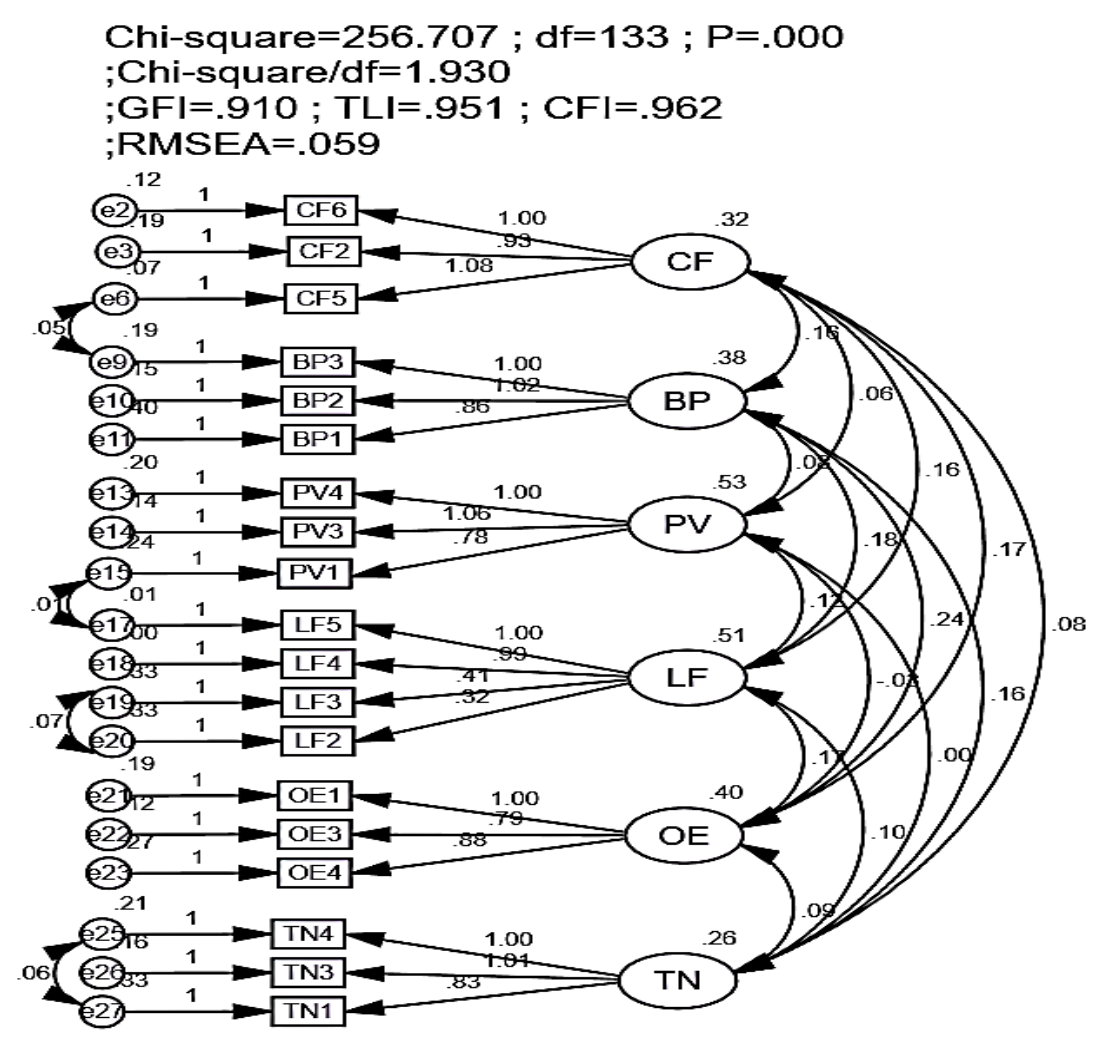

Figure 2 - CFA results (normalized)

(Source: authors' own analysis of the research data via SPSS 22.0)

Inspection of the relationship between the characteristics of SMEs and the credit accessibility for them

Structural equation modelling (SEM) has been performed to explore the relationship between the structure of SMEs characteristics and the access to bank credit for SMEs. Check of the basic relationship between the elements (Location of the Firm (LF), Owners' Equity (OE), Business Plan (BP), Firm's Collateral (FC), Firm's Project Value (PV) and Firm Tax (TN) and the access to bank credit was performed.

The results show that the valid Chi-square statistics of this model is 479,417 with 184 degrees of freedom, $\mathrm{p}=0.000$ for $\mathrm{cmin} / \mathrm{df}$ squared counterpart is 2,606 (<3). Other indicators are GLI $=0.870(>0.8)$, TLI $=0.900(>0.9)$, CFI $=0.920(>0.9)$ and $\mathrm{RMSEA}=$ 0.077 (<0.08). Therefore, this model demonstrates compatibility with the collected data. More specifically, such factors as

(1) Firm's Business Plan (ES $=0.295 ; \mathrm{P}=0.000)$;

(2) Location of the Firm ( $\mathrm{ES}=0.275 ; \mathrm{P}=0,000)$;

(3) Firm Tax $(\mathrm{ES}=0.206 ; \mathrm{P}=0.011)$;

(4) Firm's Collateral ( $\mathrm{ES}=0.119 ; \mathrm{P}=0.022)$;

(5) Firm's Project Value (ES $=0.118 ; \mathrm{P}=0.003)$ and

(6) Owners' Equity (ES $=0.101 ; \mathrm{P}=0.011$ ) have the $\mathrm{P}$-values $<0.05$ and the estimated values are normalized so that they have a direct effect on credit accessibility for SMEs. 


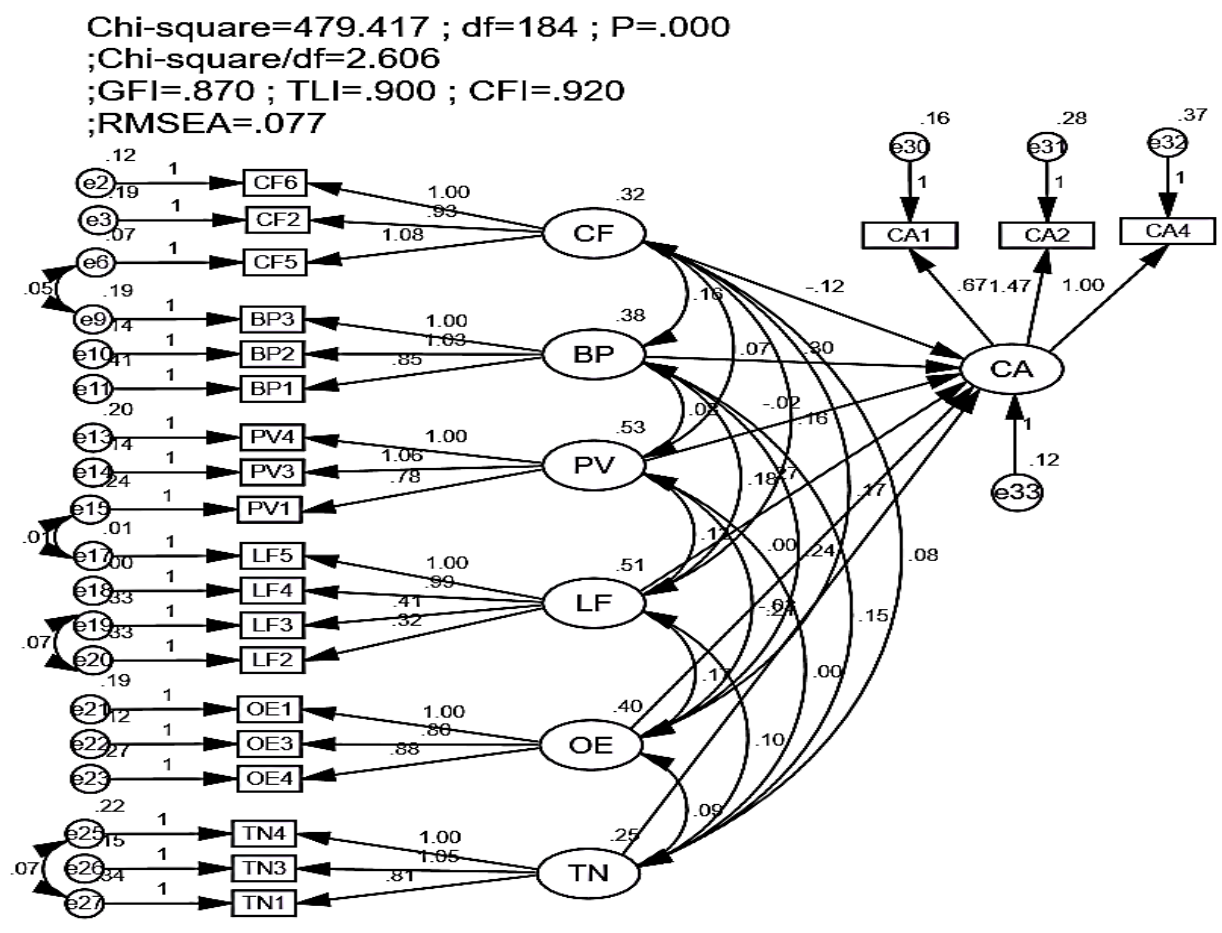

Table 2 - Results of estimating causal relationship between SMEs characteristics and bank credit accessibility

(Source: authors' own analysis of the research data via SPSS 22.0)

\begin{tabular}{lcccccc}
\hline \multicolumn{2}{c}{ Relations } & Estimate & S.E. & C.R. & P \\
\hline CA & $<--$ & CF & 0.119 & 0.064 & 1.865 & 0.022 \\
CA & $<---$ & BP & 0.295 & 0.086 & 3.439 & $* * *$ \\
CA & $<---$ & PV & 0.118 & 0.045 & 0.408 & 0.003 \\
CA & $<---$ & LF & 0.275 & 0.051 & 5.39 & $* * *$ \\
CA & $<---$ & OE & 0.101 & 0.072 & 0.012 & 0.021 \\
CA & $<---$ & TN & 0.206 & 0.081 & 2.533 & 0.011 \\
\hline
\end{tabular}

\section{Testing the reliability of estimates by means of bootstrap}

The bootstrap method used to test the model estimates the last model with the pattern repeat is $\mathrm{N}=1000$. The estimation results on 1000 samples are averaged together with the deviations presented in Table 4 . CR has a very small absolute value, below 2, thus, it can be said that the deviation is very small while not statistically significant at the $95 \%$ confidence level. Thus, we can conclude that the model estimates can be trusted.

As a result of testing the hypotheses for SMEs characteristics, the hypotheses $\mathrm{H} 1, \mathrm{H} 2$, $\mathrm{H} 3 \mathrm{H} 4, \mathrm{H} 5$, and H6 are accepted. These are six relationships that are worth studying theoretically in more detail. 


\section{BANK CREDIT ACCESSIBILITY FOR SMALL}

Table 4 - Results estimated by bootstrap with $\mathrm{N}=1000$

(Source: authors' own analysis of the research data via SPSS 22.0)

\begin{tabular}{|c|c|c|c|c|c|c|c|c|}
\hline & & \multicolumn{4}{|c|}{ Estimate standard } & \multicolumn{3}{|c|}{ Estimate Bootstrap with $\mathrm{N}=1000$} \\
\hline \multicolumn{3}{|c|}{ Parameter } & SE & SE-SE & Mean & Bias & SE-Bias & CR \\
\hline $\mathrm{CA}$ & $<---$ & $\mathrm{CF}$ & 0.1 & 0.002 & -0.107 & -0.012 & 0.003 & -4.00 \\
\hline CA & $<---$ & $\mathrm{BP}$ & 0.138 & 0.003 & 0.272 & -0.023 & 0.004 & -5.75 \\
\hline $\mathrm{CA}$ & $<---$ & PV & 0.053 & 0.001 & -0.011 & 0.007 & 0.002 & 3.50 \\
\hline $\mathrm{CA}$ & $<---$ & $\mathrm{LF}$ & 0.095 & 0.002 & 0.265 & -0.01 & 0.003 & -3.33 \\
\hline CA & $<---$ & $\mathrm{OE}$ & 0.145 & 0.003 & 0.024 & -0.023 & 0.005 & -4.60 \\
\hline $\mathrm{CA}$ & $<---$ & $\mathrm{TN}$ & 0.091 & 0.002 & 0.19 & -0.016 & 0.003 & -5.33 \\
\hline
\end{tabular}

\section{Conclusions}

Out of 300 businesses considered initially, 264 businesses (or 89.6\%) have applied for credit from commercial banks. The results indicate that in addition to equity capital, commercial banks are the next big source of potential capital for SMEs. The results are consistent with the conclusion stating that among the SMEs' capital structure decisions bank borrowing is the most common source of capital, after internal equity however. Out of 264 respondents who have applied for credit from commercial banks, 216 respondents (or 72.0\%) got full credit from commercial banks. These results are consistent with the conclusion of Stiglitz (1981).

Linear regression analysis shows the likelihood of receiving all or part of credit is based on several dependent variables, such as reporting. Other meaningful variables include cash flow statements, availability of a developed business plan, project value, availability of collateral, location of SMEs.

Our results indicate that business taxes and collateral, management capacity (especially high education and the related business experience), business plan and project value, relationship with banking institutions and business position are important determinants of SMEs' access to bank credit. In addition, incorporation and size of a company were also found to be important factors.

The research recommends that in order to receive loans from banks, a company owner needs to think of a potential business or personal asset to be used as collateral. Therefore, in order to get the necessary funding from commercial banks, the first thing to do is to demonstrate the intention that the owners of SMEs are ready to invest. In addition, over the years, governments and other public agencies have used considerable resources to develop and implement various credit market interventions. It is important that these interventions be effective and responsive to the needs of the people they claim to support.

Research focuses strictly on bank credit accessibility. The determinants of other sources of credit for SMEs, such as commercial credit and government support, have not been investigated as such. In addition, the study focuses on the demand side only. In future research, it would be possible to investigate the determinants of credit approval on the side of banks. 


\section{References:}

1. Abor, J. (2008). Determinants of the Capital Structure of Ghanaian firms. African Economic Research Consortium, Research Department.

2. Abor, J. (2007). Industry Classification and the Capital Structure of Ghanaian SMEs. Studies in Economics and Finance, 24(3), 207-219.

3. Baculáková, K. \& Grešš, M. (2015). Cluster analysis of creative industries in the EU. Economic annals-XXI, 9-10, 15-18.

4. Barbosa, E. G. \& Moraes, C. C. (2004). Determinants of the firm's capital structure: The case of the very small enterprises. Available online at: https://econwpa.ub.uni-muenchen.de/econwp/fin/papers/0302/0302001.pdf.

5. Berger, A. \& Udell, G. (2006). A more conceptual framework for SME financing. Journal of Banking and Finance, 30(11), 2945-2966.

6. Coco, G. (2000). On the use of collateral. Journal of Economic Surveys, 14(2), 191-214.

7. Da Silva A. P., Hall G. \& Hutchinson P. (2007). Financial and Strategic Factors Associated with the Profitability and Growth of Small and Medium-Sized Firms in Portugal. A paper presented at International Council for Small Business, 52nd World Conference, 13th -15 th June, Turku, Finland.

8. Demirguc-Kunt, A., Maksimovic, V., Beck, T. \& Laeven, L. (2006). The determinant of financing obstacles. International Journal of Money and Finance, 25, 932-952.

9. Fatoki, O. \& Asah, F. (2011). The Impact of Firm and Entrepreneurial Characteristics on Access to Debt Finance by SMEs in King Williams' Town, South Africa. International Journal of Business and Management, 6(8).

10. Gilbert, B. A. (2008). New venture performance: does location matter? Available online at: http://ftp.zew.de/pub/zew-docs/entrepreneurship/Gilbert.pdf.

11. Hall, G., Hutchinson, P. \& Michealas, N. (2000). Industry effect on the determinants of Unquoted SMEs Capital Structure. International Journal of the Economic of Business, 7(3), 297-312.

12. Kitindi, E. G., Magembe, B. A. S. \& Sethibe, A. (2007). Lending decision making and financial information: the usefulness of corporate annual reports to lender in Botswana. International Journal of Applied Economics and Finance, 1(2), 55-60.

13. Modigliani, F. \& Miller, M. H. (1963). Corporate income taxes and the cost of capital: A correction. The American Economic Review, 53(3), 433-443.

14. Myers, S. C. (1984). Capital structure puzzle. Journal of Finance, 39(1), 575-592.

15. Olutunla, G. T. \& Obamuyi, T. M. (2008). An empirical analysis of factors associated with the profitability of Small and medium-sized enterprises in Nigeria. African Journal of Business Management, 2(x), 195-200.

16. Popkova, E.G., Zolochevskaya, E.Y., Litvinova, S.A. \& Zima, Y.S. (2017). New Scenarios Of Joint Crises Fighting In Socio-Economic Sphere Of Russia And Greece. European Research Studies Journal, 20(1), 49-55.

17. Shane, S. (2008). The importance of angel investing in financing the growth of entrepreneurial ventures. Quarterly Journal of Finance, 2 (02), 1-42. 


\section{BANK CREDIT ACCESSIBILITY FOR SMALL}

18. Sorooshian, S., Norzima, Z., Yusuf, I. \& Rosnah,Y. (2010). Structural Modeling of Entrepreneurships effectiveness. World Applied Sciences Journal, 10(8), 923-929.

19. Stepanova, D. I., Garnov, A.P., Brykin, A.V. \& Jančíková, E. (2019). Irrational Behaviour of Youth When Taking Financial Decisions. International Journal of Economics \& Business Administration, 7(1), 378-387

20. Stiglitz, J. \& Weiss, A. (1981). Credit rationing in markets with imperfect information. American Economic Review, 71, 393-410.

Paper submitted

Paper accepted for publishing

Paper published online
04 December 2020

11 February 2021

31 March 2021 